\title{
PENGEMBANGAN MODEL PEMBELAJARAN TGFU UNTUK MENINGKATKAN TEKNIK DASAR SEPAK CUNGKIL DAN SEPAK SILA SEPAK TAKRAW
}

\author{
Arief Darmawan ${ }^{1}$, Zihan Novita Sari ${ }^{2}$, Tatok Sugiarto ${ }^{3}$, Sugiyanto ${ }^{4}$, Surya Adi Saputra ${ }^{5}$ \\ 1,23,4,5 Program Studi Pendidikan Jasmani, Kesehatan dan Rekreasi, Fakultas IImu Keolahragaan, \\ Universitas Negeri Malang \\ E-mail: arief.darmawan.fik@um.ac.id¹, zihan.novita.fik@um.ac.id², tatok.sugiarto.fik@um.ac.id³, \\ Sugiyanto.fik@um.ac.id4 ${ }^{4}$, surya.adi.fik@um.ac.id 5 \\ DOI: https://doi.org/10.36526/kejaora.v6i2.1523
}

\begin{abstract}
ABSTRAK
Tujuan dari penelitian ini adalah membuat model pembelajaran TGFU untuk meningkatkan teknik dasar sepak cungkil dan sepak sila pada sepak takraw. Model ini dibuat dan di unggah di Sipejar Universitas Negeri Malang agar nantinya para mahasiswa menjadi mudah memperoleh materi dari dosen pengajar mata kuliah sepak takraw. Pendekatan penelitian menggunakan mixed method. Sedangkan metode penelitiannya menggunakan metode research \& development (Borg and Gall), menggunakan langkah kesatu sampai langkah ketujuh. Analisis kebutuhan penelitian dan pengembangan model pembelajaran TGFU untuk mahasiswa PJKR dilakukan wawancara sederhana kepada 12 orang mahasiswa yang sedang mengikuti perkuliahan sepak takraw. Berdasarkan analisis kebutuhan yaitu masih belum optimal pembelajaran yang dilakukan hal ini dapat terlihat dari antusias mahasiswa yang kurang aktif dan belum mengetahui apa yang akan dilakukan, kemudian kesulitan gerakan dalam permainan. Hasil uji kecil dan uji besar meyatakan bahwa produk ini layak digunakan. Sedangkan uji eksperimen menggunakan desain one shot case study menyatakan bahwa ada peningkatan yang signifikan setelah mahasiswa diberikan pembelajaran menggunakan TGFU, hal ini dapat terlihat nilai sig-2 tailed yang menunjukkan hasil $0.358>0,05$ untuk sepak cungkil, dan 0,434 >0,05 untuk sepak sila.
\end{abstract}

Kata Kunci: Pengembangan, TGFU, Sepak Takraw

\section{PENDAHULUAN}

Olahraga sudah merupakan bagian dari kehidupan menusia bahkan sudah masuk menjadi kebutuhan hidup, terbukti begitu banyak bentuk dan jenis kegiatan olahraga yang diperlukan. Apalagi setelah dicanangkannya motto "memasyarakatkan olahraga dan mengolahragakan masyarakat" dan "tiada hari tanpa olahraga". Di Indonesia olahraga sudah cukup memasyarakat, baik secara jalur formal, nonformal, maupun informal. Secara formal olahraga sudah menjadi materi pokok disetiap jenjang pendidikan seperti SD, SMP, SMA, bahkan sampai Perguruan Tinggi.

Fakultas IImu Keolahragaan adalah salah satu fakultas yang ada di Universitas Negeri Malang. dalam fakultas tersebut ada beberapa program studi antara lain prodi pendidikan kepelatihan dan prodi pendidikan jasmani, kesehatan dan rekreasi. Sepaktakraw adalah salah satu matakuliah yang ada dalam kedua prodi tersebut. Dalam masa pandemic Covid-19 seperti sekarang ini dilakukan pembelajaran Syncronus dan Asyncronus di Universitas Negeri Malang. Pembelajaran di Universitas Negeri Malang menggunakan aplikasi Sipejar dalam pembelajarannya sehingga dibutuhkan Video pembelajaran dan elektronik book sepaktakraw yang di upload di Sipejar untuk mempermudah proses pembelajaran dosen dengan mahasiswa.

Pada permainan sepaktakraw terdapat berbagai macam teknik dasar yang wajib dikuasai dengan baik karena diharapkan mampu diimplementasikan dalam permainan sepaktakraw (Rachman, 2008)

Tujuan dalam sepak takraw adalah mahasiswa dapat melakukan permainan dan 
menguasai teknik dasar sepak takraw. Keterampilan dasar diperlukan dalam menghadapi pertandingan, agar pemain dapat memenangkannya. Model Teaching Games For Understanding (TGFU) merupakan suatu pendekatan pembelajaran pendidikan jasmani untuk memperkenalkan bagaimana anak mengerti olahraga melalui bentuk konsep dasar bermain (Hastie \& Curtner-Smith, 2006; Jarrett et al., 2014; Morillo-Baro et al., 2015; Setyawan, n.d.).

Empat dasar prinsip pendidikan dalam TGFU adalah Sampling, ModificationRepresentation, Modification-Exaggeration, Tactical Complex (Arias-Estero et al., 2020; Artha et al., 2020). Permainan dengan kompleksitas yang rendah membentuk titik awal untuk memberi pemahaman kepada anak-anak (Tangahu, 2019).

Latihan teknik dasar ini harus dilakukan secara berulang-ulang untuk mendapatkan hasil yang maksimal (Wardana et al., 2018). Selain ketepatan atau akurasi, teknik menendang bola yang baik juga membutuhkan kecepatan (Adi et al., 2019).

Penulis nantinya menggunakan 4 langkah pembelajaran pendekatan TGFU yaitu: Game 1, Pertanyaan, Latihan dan Game 2. Tanpa penguasaan teknik dasar dengan baik, permainan tidak dapat dimainkan dengan sempurna. Namun apabila pemain dapat menguasai teknik dengan baik maka permainan akan dapat dilaksanakan dengan baik sehingga tercipta kemenangan.

Atas dasar latar belakang masalah di atas maka akan dilakukan satu penelitian dengan judul "Pengembangan Model Pembelajaran Tgfu Untuk Meningkatkan Teknik Dasar Sepak Cungkil dan Sepak Sila Sepak Takraw".

\section{METODE}

Penelitian dan pengembangan model pembelajaran TGFU untuk meningkatkan Sepakcungkil dan Sepaksila sepaktakraw untuk mahasiswa FIK Universitas Negeri Malang ini merupakan suatu proses yang bertujuan mengembangkan model.

Tempat penelitiannya dilaksanakan di Universitas Negeri Malang, sedangkan subyek penelitian ini adalah mahasiswa Pendidikan jasmani yang mengambil matakuliah sepaktakraw. Waktu penelitian dimulai dari bulan April sampai bulan Oktober 2021.

Pendekatan penelitian menggunakan mixed method (gabungan penelitian kualitatif dan kuantitatif). Dalam penelitian dan pengembangan model pembelajaran TGFU untuk meningkatkan Sepakcungkil dan Sepaksila pada sepaktakraw pada mahasiswa FIK Universitas Negeri Malang ini merupakan suatu proses yang bertujuan mengembangkan model pembelajaran TGFU yang efektif dan efisien. Sedangkan pada tahap uji efektivitas ,untuk menganalisis data nya menggunakan statistik deskriptif, yaitu analisis persentase dan rerata. Adapun norma tes sepak cungkil dan sepak sila selama 3 menit diambil dari buku Hanif (2020) dijabarkan pada tabel dibawah ini:

Tabel 1. Norma Tes Sepakcungkil dan sepaksila selama 3 menit

\begin{tabular}{ll}
\hline Normatif & Kategori \\
\hline Sangat Baik & $>172$ \\
\hline Baik & $156-171$ \\
\hline Cukup & $132-155$ \\
\hline Kurang & $108-131$ \\
\hline Kurang Sekali & $<107$ \\
\hline
\end{tabular}

\section{HASIL DAN PEMBAHASAN \\ Hasil Analisis Kebutuhan}

Tahap pertama penelitian yaitu analisis kebutuhan dengan wawancara, dan observasi pelaksanaan pembelajaran. Need assesment diperoleh untuk mengetahui permasalahan-permasalahan yang ada pada perkuliahan. Masih adanya permasalahan yang dilakukan di mahasiswa yaitu masih belum optimal pembelajaran yang dilakukan, hal ini terlihat dari antusias masiswa yang kurang aktif dan belum tau apa yang akan dilakukan, kemudian kesulitan gerakan dalam permainan.

Analisis kebutuhan penelitian dan pengembangan model pembelajaran TGFU dilakukan dengan wawancara kepada 12 orang mahasiswa yang sedang mengikuti perkuliahan sepaktakraw. Analisis kebutuhan digunakan untuk mengetahui adanya kebutuhan akan pengembangan. 
Hasil observasi menunjukkan bahwa hasil belajar mahasiswa masih sangat rendah. Sehingga dirasakan perlu pembuatan model pembelajaran TGFU untuk meningkatkan teknik dasar sepakcungkil dan sepaksila sepaktakraw. sehingga, hasil dari need assesment ini, pengembangan model TGFU untuk meningkatkan sepakcungkil dan sepaksila sepaktakraw dirasa perlu dilakukan.

\section{Perancangan dan Pengembangan Produk} Draft awal disusun setelah diketahui adanya need assesment. Perancangan produk diawali dengan analisis terkait dengan model sepaktakraw berbasis TGFU. Assesment dari ahli terdiri dari: 1 Ahli sepaktakraw, 1 ahli pembelajaran, dan 1 ahli dari Dosen pengampu matakuliah. Para ahli mencermati produk model yang telah dibuat kepada peneliti, kemudian memberikan masukan. Pembuatan produk disesuaikan dengan CPMK yang digunakan di program studi, kemudian penyusunan pengambilan video dan gambar, menyusun semua bahan dan diakhiri dengan uji coba kepada mahasiswa.

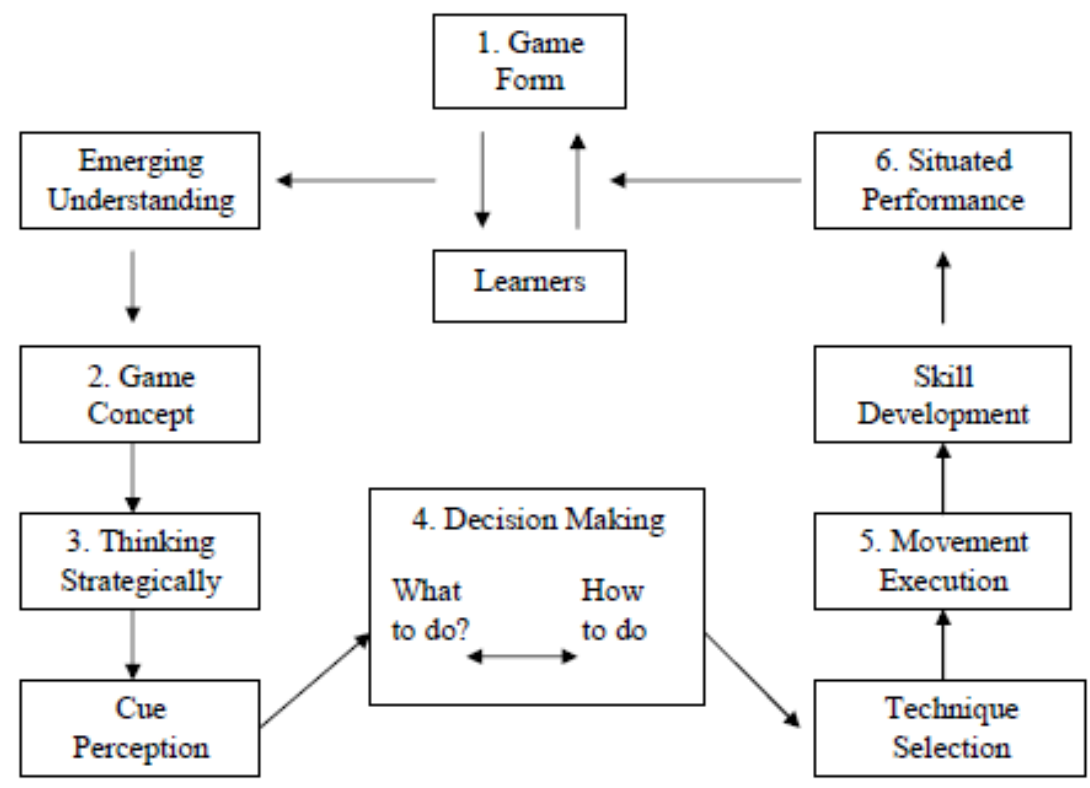

Gambar 1. Model TGFU

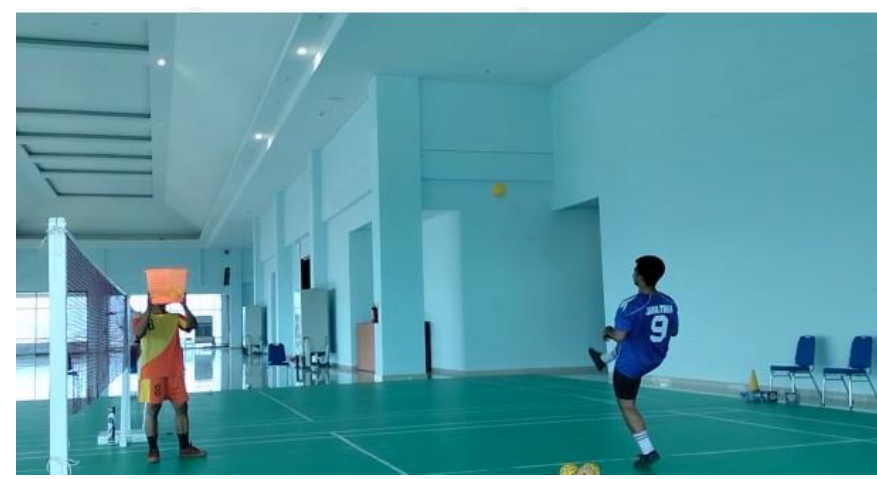

Gambar 2. Perancangan dan pengembangan Produk

Setelah diketahu hasil need asesmen, kemudian disusunlah produk. Pembuatan produk diawali dengan analisis CPMK serta literatur terkait dengan model pembelajaran 
Jurnal Kejaora: Jurnal Kesehatan Jasmani dan Olah Raga

ISSN: 2541-5042 (Online)

ISSN: 2503-2976 (Print)

Volume 6 Nomor 2, Edisi November 2021

TGFU. Hasil pengembangan ini adalah produk dalam bentuk Permainan/ tahapan pembelajaran TGFU sepaktakraw.

\section{Adapun produk ini terdiri dari:}

a) Game 1

Game 1 ini para mahasiswa melakukan 8 game modifikasi antara lain:

1. Berpasangan, satu orang melempar dan satu orang melakukan control dengan cungkil

2. Melempar bola, menendang dengan kaki bagian kura-kura/ cungkil. Dilakukan satu kali tangkap, satu kali tangkap (Individu)

3. Melempar bola, menendang dengan kaki bagian kura-kura/ cungkil. Dilakukan sepuluh kali (Individu)

4. Kontrol memakai kaki bagian kura-kura/ cungkil, kemudian diakhir bola diarahkan ke keranjang

5. Lempar, satu kali control memakai kaki bagian kura-kura/ cungkil dan sepak tangkap berpasangan

6. Lempar, dua kali control memakai kaki bagian kura-kura/ cungkil dan sepak tangkap berpasangan

7. Melakukan sepak sila, dengan bola tinggirendah

8. Melakukan sepaksila berpasangan dengan penghalang net

9. Memainkan modifikasi sepaktakraw 4 vs 4

b) Latihan

Latihan dimaksudnya kepada mahasiswa untuk mencari solusi untuk

menciptakan kemenangan, dalam sesi ini mahasiswa melakukan laihan sepaktakraw 3 vs 3 sesuai permainan. Siswa diberi latihan keterampilan teknik sesuai dengan masalah taktik pada materi.

\section{c) Game 2}

Permainan game 2 ini mirip seperti game 1. Tujuannya adalah mahasiswa diberi kesempatan untuk mengaplikasikan perkembangan keterampilan dan pemahaman taktik melalui permainan. Adapun permainannya adalah:

1. Permainan 2 vs 2

2. Permainan 4 vs 4

3. Modifikasi setengah lapangan

4. Pemain bagus melawan pemain bagus

5. Pemain berkemampuan sedang melawan pemain berkemampuan sedang

6. Game sebenarnya disesuaikan dengan peraturan ( 3 VS 3)

Hasil Keterangan Uji kecil dan uji besar dapat terlaksana dengan baik pada mahasiswa pendidikan jasmani, kesehatan dan rekreasi.

Uji coba kelompok kecil dilaksanakan pada 6 orang, sedangkan uji coba kelompok besar 40 orang peserta. Hasil Uji coba kelompok kecil, kelompok besar dan keterlaksanaan model menurut 3 orang pengamat diperoleh halsil sebagai berikut:

Tabel 2. Hasil Uji Coba Kelompok Besar Keterlaksanaan Model Oleh Pengamat

\begin{tabular}{lll}
\hline No & Kategori Game 1 & Keterangan Hasil Uji Kecil \& Uji Besar \\
\hline 1 & Variasi 1 & Model Bisa Dilakukan Dengan Baik \\
\hline 2 & Variasi 2 & Model Bisa Dilakukan Dengan Baik \\
\hline 3 & Variasi 3 & Model Bisa Dilakukan Dengan Baik \\
\hline 4 & Variasi 4 & Model Bisa Dilakukan Dengan Baik \\
\hline 5 & Variasi 5 & Model Bisa Dilakukan Dengan Baik \\
\hline 6 & Variasi 6 & Model Bisa Dilakukan Dengan Baik \\
\hline 7 & Variasi 7 & Model Bisa Dilakukan Dengan Baik \\
\hline 8 & Variasi 8 & Model Bisa Dilakukan Dengan Baik \\
\hline 9 & Variasi 9 & Model Bisa Dilakukan Dengan Baik \\
\hline No & Kategori Latihan & Keterangan Hasil Uji Kecil \& Uji Besar \\
\hline 1 & Variasi 1 & Model Bisa Dilakukan Dengan Baik \\
\hline No & Kategori Game 2 & Keterangan Hasil Uji Kecil \& Uji Besar \\
\hline 1 & Variasi 1 & Model Bisa Dilakukan Dengan Baik \\
\hline 2 & Variasi 2 & Model Bisa Dilakukan Dengan Baik \\
\hline 3 & Variasi 3 & Model Bisa Dilakukan Dengan Baik \\
\hline
\end{tabular}


Jurnal Kejaora: Jurnal Kesehatan Jasmani dan Olah Raga

ISSN: 2541-5042 (Online)

ISSN: 2503-2976 (Print)

Volume 6 Nomor 2, Edisi November 2021

\begin{tabular}{lll}
\hline 4 & Variasi 4 & Model Bisa Dilakukan Dengan Baik \\
\hline 5 & Variasi 5 & Model Bisa Dilakukan Dengan Baik \\
\hline 6 & Variasi 6 & Model Bisa Dilakukan Dengan Baik \\
\hline
\end{tabular}

Kemudian langkah selanjutnya adalah pengujian dengan desain The One Shot Case study (Maksum, 2012). Pengujian ini ditujukan kepada mahasiswa berjumlah 30 orang. Adapun desainnya adalah sebagai berikut:

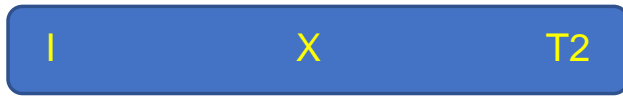

Gambar 3. Desain The One Shot Case study

Deskripsi data memberikan gambaran tentang tes akhir, rerata dan standar deviasi. Perolehan data dapat dilihat pada tabel $2 \mathrm{di}$ bawah ini.

\begin{tabular}{ccc}
\multicolumn{3}{c}{ Tabel 3. Perolehan data tes akhir } \\
\hline No & $\begin{array}{c}\text { Tes Akhir } \\
\text { Sepak } \\
\text { Cungkil }\end{array}$ & $\begin{array}{c}\text { Tes Akhir } \\
\text { Sepak Sila }\end{array}$ \\
\hline 1 & 133 & 130 \\
\hline 2 & 134 & 132 \\
\hline 3 & 138 & 136 \\
\hline 4 & 140 & 138 \\
\hline 5 & 156 & 155 \\
\hline 6 & 157 & 157 \\
\hline 7 & 156 & 156 \\
\hline 8 & 132 & 133 \\
\hline 9 & 133 & 133 \\
\hline 10 & 160 & 159 \\
\hline 11 & 162 & 163 \\
\hline 12 & 163 & 161 \\
\hline 13 & 164 & 164 \\
\hline
\end{tabular}

\begin{tabular}{ccc}
\hline 14 & 156 & 155 \\
\hline 15 & 156 & 156 \\
\hline 16 & 135 & 135 \\
\hline 17 & 136 & 135 \\
\hline 18 & 138 & 157 \\
\hline 19 & 138 & 134 \\
\hline 20 & 133 & 133 \\
\hline 21 & 135 & 134 \\
\hline 22 & 156 & 151 \\
\hline 23 & 132 & 133 \\
\hline 24 & 132 & 133 \\
\hline 25 & 156 & 155 \\
\hline 26 & 156 & 150 \\
\hline 27 & 158 & 158 \\
\hline 28 & 160 & 160 \\
\hline 29 & 156 & 155 \\
\hline 30 & 150 & 151 \\
\hline Rerata & 147 & 146 \\
\hline Standart & 11,91 & 11,96 \\
Deviasi & & \\
\hline & &
\end{tabular}

Hasil data diatas merupakan hasil tes dari sepakcungkil dan sepaksila yang dilakukan selama 3 menit. Dengan dugaan rata-rata nilai tes sepakcungkil dan sepaksila mahasiswa adalah 145 . Pada hasil tabel diatas menunjukkan bahwa terdapat hasil yang memuaskan pada hasil teknik dasar sepakcungkil dan sepaksila setelah diberikan model pembelajaran TGFU. Adapun Hasil penghitungan dilakukan menggunakan SPSS sepakcungkil dapat dilihat pada tabel dibawah ini:

Tabel 4. One-Sample Statistics

N Mean Std. Deviation Std. Error Mean

\begin{tabular}{lllll}
\hline Sepak Cungkil & 30 & $1.4703 E 2$ & 11.91777 & 2.17588 \\
\hline
\end{tabular}


Tabel 5. One-Sample Test

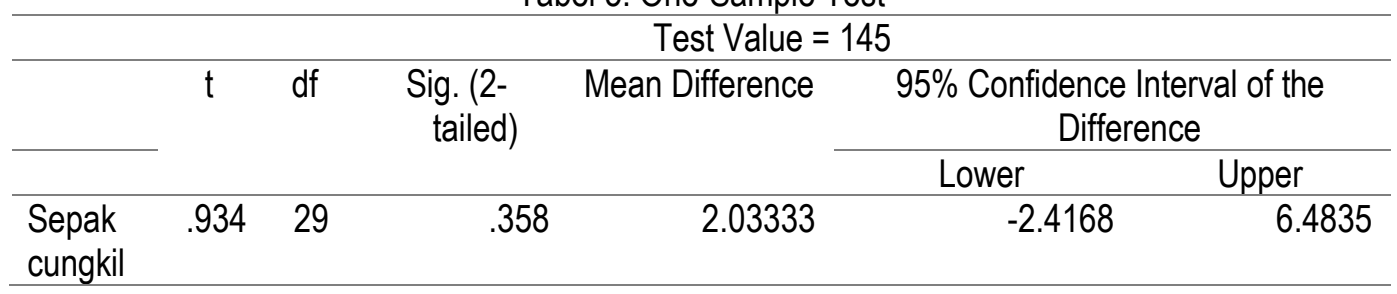

Dasar pengambilan keputusan dalam pengujian hipotesis adalah:

a) Jika signifikansi $(p)>0,05$ maka $\mathrm{H}_{0}$ diterima.

b) Jika signifikansi $(p)<0,05$ maka $\mathrm{H}_{0}$ ditolak.

Berdasarkan pada tabel 3 di atas sudah terlihat data secara terperinci Perolehan data tes akhir sepakcungkil, kemudian diperlihatkan data menggunkan spss pada tabel 4 dan 5 . Hal ini menunjukkan bahwa tingkat signifikansi adalah $(p)<0,05$. Sehingga dapat disimpulkan bahwa hasil setelah diberikan model pembelajaran TGFU menunjukkan tingkat signifikansi dengan baik. Adapun Hasil penghitungan dilakukan menggunakan SPSS Sepaksila dapat dilihat pada tabel dibawah ini:

Tabel 6. One-Sample Statistics

\begin{tabular}{|c|c|c|c|c|c|}
\hline & $\mathrm{N}$ & Mean & Std. Deviation & $\begin{array}{c}\text { Std. } \\
\text { Error Mean }\end{array}$ & \\
\hline $\begin{array}{l}\text { Sepak } \\
\text { sila }\end{array}$ & 30 & 1.4673E2 & 11.96816 & & 2.18508 \\
\hline \multicolumn{6}{|c|}{ Tabel 7. One-Sample Test } \\
\hline & \multicolumn{5}{|c|}{ Test Value $=145$} \\
\hline & \multirow[t]{2}{*}{$t \quad d f$} & \multirow[t]{2}{*}{$\begin{array}{l}\text { Sig. (2- } \\
\text { tailed) }\end{array}$} & \multirow[t]{2}{*}{$\begin{array}{c}\text { Mean } \\
\text { Difference }\end{array}$} & \multicolumn{2}{|l|}{$\begin{array}{l}\text { 95\% Confidence Interval of the } \\
\text { Difference }\end{array}$} \\
\hline & & & & Lower & Upper \\
\hline $\begin{array}{l}\text { Sepak } \\
\text { sila }\end{array}$ & $.793 \quad 29$ & .434 & 1.73333 & -2.7356 & 6.2023 \\
\hline
\end{tabular}

Berdasarkan pada tabel 3 di atas sudah terlihat data secara terperinci Perolehan data tes akhir sepaksila, kemudian diperlihatkan data menggunkan spss pada tabel 6 dan 7. Hal ini menunjukkan bahwa tingkat signifikansi adalah $(p)<0,05$. Sehingga dapat disimpulkan bahwa hasil setelah diberikan model pembelajaran TGFU menunjukkan peningkatan yang signifikan.

\section{Pembahasan}

Hasil dari penelitian ini memberikan dampak yang baik mengingat dalam proses uji coba dapat dilaksanakan dengan baik. sementara itu hasil eksperimen menggunakan desain The One Shot Case study berkesimpulan bahwa hasilnya signifikan. Hal tersebut dapat dilihat dari nilai (p) < 0,05. setelah diberikan model pembelajaran TGFU menunjukkan tingkat signifikansi. Hasil penelitian tersebut sejalan dengan penelitian dari Ramadhan (2018) menjelaskan bahwa model pembelajaran sepaktakraw melalui TGFU berhasil meningkatkan sepaksila. Sementara itu Saputra (2016) menjelaskan bahwa Model Pembelajaran Teaching Games For Understanding (TGFU) berpengaruh terhadap Hasil Pembelajaran Sepak Takraw. Adapun Dania et al., (2017) melakukan penelitian tentang TGFU yang berkesimpulan bahwa TGfU memfasilitasi 
Jurnal Kejaora: Jurnal Kesehatan Jasmani dan Olah Raga

ISSN: 2541-5042 (Online)

ISSN: 2503-2976 (Print)

Volume 6 Nomor 2, Edisi November 2021

perkembangan dan kinerja siswa dalam hal tingkat PA di kelas mereka. Amirullah (2008) menegaskan bahwa TGFU bertujuan untuk meningkatkan kemampuan anak dalam melakukan olahraga permainan yang didukung oleh pemahaman taktik yang baik serta penguasaan keterampilan teknik dasar yang baik pula.

\section{KESIMPULAN}

Berdasarkan hasil pengolahan dan analisis data diperoleh simpulan hasil penelitian yang telah dijalani. Adapun simpulan yang diperoleh adalah Model pembelajaran TGFU dapat dikembangkan dan diterapkan dalam perkuliahan di prodi pendidikan jasmani serta dapat meningkatkan hasil belajar sepakcungkil dan sepaksila mahasiswa pendidikan jasmani, kesehatan dan rekreasi

\section{DAFTAR PUSTAKA}

Adi, I. H., Setiabudi, M. A., \& Santoso, D. A. (2019). Perbandingan Kecepatan Dan Ketepatan Menendang Bola Dengan Menggunakan Awalan 1 Meter, 2 Meter, 3 Meter, 4 Meter. Jurnal Kejaora (Kesehatan Jasmani Dan Olahraga), 4(1), 12-15. https://doi.org/10.36526/kejaora.v4i1.6 16

Arias-Estero, J. L., Jaquero, P., MartínezLópez, A. N., \& Morales-Belando, M. T. (2020). Effects of two TGFU lessons period on game performance, knowledge and psychosocial variables in elementary physical education. International Journal of Environmental Research and Public Health, 17(10). https://doi.org/10.3390/ijerph17103378

Artha, A. A., Syam T, A. R., \& Priambodo, A. (2020). The Application of Teams Games Tournament (TGT) and Teaching Game for Understanding (TGfU) Learning Models on Learning Motivation and Volley Ball Passing Skills. Budapest International Research and Critics in Linguistics and Education (BirLE) Journal, 3(1), 46-53. https://doi.org/10.33258/birle.v3i1.751

Dania, A., Kossyva, I., \& Zounhia, K. (2017). Effects Of A Teaching Games For

Understanding Program On Primary School Students ' Physical Activity Patterns. European Journal of Physical Education and Sport Science, 81-94. https://doi.org/10.5281/zenodo.400591

Hanif, A. S. (2020). Kepelatihan Dasar Sepak Takraw. Jakarta: PT Raja Grafindo Persada.

Hastie, P. A., \& Curtner-Smith, M. D. (2006). Influence of a hybrid Sport EducationTeaching Games for Understanding unit on one teacher and his students. Physical Education \& Sport Pedagogy, 11(1), 1-27. https://doi.org/10.1080/174089805004 66813

Jarrett, K., Eloi, S., \& Harvey, S. (2014). Teaching Games for Understanding (Tgfu) As a Positive and Versatile Approach To Teaching Adapted Games. European Journal of Adapted Physical Activity, 7(1), 6-20. https://doi.org/10.5507/euj.2014.001

Maksum, A. (2012). Metodologi Penelitihan Dalam Olahraga. Surabaya: Universitas Negeri Surabaya University Press.

Morillo-Baro, J. P., Reigal, R. E., \& Hernández-Mendo, A. (2015). Análisis del ataque posicional de balonmano playa masculino y femenino mediante coordenadas polares. RICYDE: Revista Internacional de Ciencias Del Deporte, 11(41), 226-244. https://doi.org/10.5232/ricyde

Rachman, H. A. (2008). Teaching Games For Understanding (Tgfu): Memahami Pendekatan Taktik Sebagai Model Pembelajaran Dalam Pendidikan Jasmani. Jurnal Pendidikan Jasmani Indonesia, 5(November), 1-10.

Saputra, M. T. (2016). Pengaruh Model Pembelajaran Sepaktakraw melalui TGFU. Universitas Pendidikan Indonesia.

Setyawan, F. B. (n.d.). Teaching Games for Understanding ( Tgfu ) ( the Concept and Its Implementation in Teaching Physical Education on Prodi State Uad ). 104-108.

Tangahu, D. F. (2019). Pengaruh Model Pembelajaran Tgfu Dan Tgt Terhadap 
Jurnal Kejaora: Jurnal Kesehatan Jasmani dan Olah Raga

ISSN: 2541-5042 (Online)

ISSN: 2503-2976 (Print)

Volume 6 Nomor 2, Edisi November 2021

Academic Learning Time. Jurnal Kejaora (Kesehatan Jasmani Dan Olahraga), $\quad 4(2), \quad 28-35$. https://doi.org/10.36526/kejaora.v4i2.7 45

Wardana, C. R., Setiabudi, M. A., \& Candra, A. T. (2018). Pengaruh Latihan SmallSided Games Terhadap Keterampilan Passing, Controlling dan Shooting Peserta Ekstrakurikuler Sepakbola SMK Negeri 1 Tegalsari Kabupaten Banyuwangi. Jurnal Kejaora (Kesehatan Jasmani Dan Olahraga), 3(2), 194-201. https://doi.org/10.36526/kejaora.v3i2.2 12 